\title{
ANALISIS STRUKTUR IKLAN WARUNG BU KRIS
}

\author{
Agus Darma Yoga Pratama \\ Universitas Warmadewa \\ agusdarmayoga85@yahoo.com \\ Ni Komang Purwaningsih \\ STIKES Bina Usadha Bali \\ purwacham89@gmail.com
}

\begin{abstract}
ABSTRAK
Penelitian ini membahas tentang struktur iklan, strategi iklan, serta pengaruh promosi iklan terhadap keputusan pembelian produk makanan Warung Bu Kris. Data dalam penelitian ini dikumpulkan melalui metode simak, yaitu dengan mengamati penggunaan kata, frasa, kalimat, ikon, maupun gambar pada iklan produk makanan di media sosial instagram Warung Bu Kris. Peneliti melakukan teknik dokumentasi melalui rekam layar, yaitu dengan menggambil gambar iklan dan mengelompokkannya. Data yang telah terkumpul selanjutnya dianalisis sesuai dengan permasalahan yang diangkat. Metode analisis data yang digunakan adalah metode padan intralingual. Hasil analisis menunjukkan bahwa struktur yang terdapat dalam iklan produk makanan Warung Bu Kris adalah kepala (headline)-ilustrasi (illustrations)-badan (body copy)- logo (signature line)-penutup (standing details) dan kepala (headline)-badan (body copy)-logo(standing line). Struktur iklan tersebut mencerminkan strategi pemasaran yang digunakan oleh pemilik Warung Bu Kris, meliputi memberikan bukti kelayakan (establishing credentials), taktik penekanan (pressure tactics), serta menawarkan insentif (offering incentives). Iklan yang ditampilkan melalui instagram selanjutnya dapat memengaruhi keputusan pembelian produk makanan Warung $\mathrm{Bu}$ Kris, terutama dalam hal attitude towards the ad serta click throught rates.
\end{abstract}

Kata kunci: iklan; makanan; promosi; struktur

\begin{abstract}
This research investigated advertising structure, strategy, and also the impact of advertising promotion on purchasing decisions of Warung Bu Kris's food. The data in this study were collected through the observation method, namely by observing the use of words, phrases, sentences, icons, and images in food product advertisements and grouping them. The researcher used screenshots as a documentation technique in collecting the data and then categorizing them into groups. The data was analyzed based on the problems raised. The intralingual method used in this research. The finding showed that the structure in the food advertisement of Warung Bu Kris was headlineillustrations-body copy-signature line-standing details and headline-body copy-standing line. The advertising structure reflected the marketing strategy used by Warung Bu Kris' owner, including establishing credentials, pressure tactics, and also offering incentives. The advertisements on Instagram influenced customer demand for food in terms of attitude towards the ad and click through rates.
\end{abstract}

Keywords: advertisement; food; promotion; structure

\section{PENDAHULUAN}

Terdapat beragam cara yang dapat dilakukan guna meningkatkan perekonomian, salah satunya dengan berwirausaha. Wirausahawan mulai bermunculan di daerah- daerah dengan karakteristik usaha yang berbeda-beda. Namun, jenis usaha yang paling digemari saat ini adalah usaha kuliner. Banyak wirausahawan gemar berbisnis kuliner. Hal ini disebabkan oleh dua faktor. Pertama, yaitu 
potensi pasar yang besar dan terus-menerus. Makanan merupakan kebutuhan dasar yang harus dipenuhi manusia. Ini menunjukkan bahwa setiap harinya orang-orang pasti mengonsumsi dan menghabiskan makanan saat itu juga dan kejadian itu terjadi secara berulang. Konsumsi yang berulang-ulang merupakan potensi pasar yang besar sehingga tercipta permintaan makanan. Kedua, usaha kuliner merupakan usaha yang sangat fleksibel. Hal ini disebabkan bisnis kuliner dimulai dengan modal sedikit. Jumlah makanan yang diproduksi dapat disesuaikan dengan jumlah modal yang dimiliki serta dapat menggunakan peralatan yang dimiliki. Menjamurnya usaha kuliner membuat persaingan bisnis semakin ketat, sehingga setiap pelaku usaha harus mengoptimalkan ide serta kreatifitasnya untuk menghasilkan produk yang diminati oleh konsumen. Pemciptaan iklan yang kreatif, informatif, serta persuasif diwajibkan agar produk iklan dapat diterima masyarakat dengan mudah. Iklan mengemas konsep kreatifnya dengan simulasi yang diilustrasikan menggunakan setting semirip mungkin dengan realitas suatu masyarakat agar tujuan pesan dalam iklan itu tercapai serta mampu membuat masyarakat tidak sadar dan merasa bahwa mereka sudah terkena terpaan iklan itu (Anam, 2015). Salah satu cara untuk meningkatkan penjualan produk makanan yakni melalui pemasaran.

Pemasaran dapat dilakukan melalui tiga macam media. Media cetak, media audiovisual, dan media sosial. Media cetak bisa berupa koran, majalah, brosur, pamflet, serta spanduk. Media audiovisual merupakan media yang relatif mahal dan tidak terjangkau untuk pengusaha pemula karena mengiklankan suatu produk melalui media elektronik membutuhkan biaya yang cukup besar sedangkan media yang paling murah dan sering digunakan saat ini adalah media sosial. Neti (2011) mengatakan bahwa pemasaran media sosial sebagai salah satu upaya untuk mengoptimalkan media sosial guna membujuk konsumen kepada satu perusahaan, produkatau jasa yang berharga. Pemasaran media sosial merupakan proses strategis dan metodis untuk membangun pengaruh perusahaan, reputasi, dan merek dalam komunitas pelanggan potensial, pembaca, atau pendukung.
Saat ini, media sosial merupakan alat promosi dan komunikasi yang paling banyak digunakan karena berdampak signifikan terhadap perkembangan bisnis karena memiliki kelebihan diantaranya banyak pengguna serta tidak memerlukan biaya untuk membuat akun di sebuah media sosial. Jumlah pengguna internet di Indonesia pada 2020 tercatat 175, 5 juta jiwa dari jumlah populasi sebanyak 268.583.016 penduduk. Salah satu media sosial yang sedang digemari dan banyak penggunanya adalah Instagram.

Instagram merupakan layanan aplikasi berbagi foto yang pertama kali muncul melalui AppStore pada Apple. Instagram memungkinkan bagi penggunanya untuk mengambil foto, mengedit, menerapkan filter digital, dan membagikan foto ke situs situs jejaring sosial seperti facebook, twitter, dan lainnya. Media sosial instagram menyediakan beragam fasilitas yang dapat dimanfaatkan wirausahawan bagi kesuksesan usahanya. Sebagai media pemasaran, instagram mengedepankan pesan visual dan interaktivitas yang tinggi.

Salah satu usaha kuliner yang memasarkan produk makanannya adalah Warung Bu Kris. Warung Kris didirikan pada tahun 1995. Saat ini Warung Bu Kris dapat ditemukan di Bali, Bandung, dan Jakarta. Hampir semua menu bisa dipenyet, antara lain ayam, bebek, empal, iga, tempe, tahu, ikan nila, udang goreng, telur, bahkan bakso. Warung Bu Kris juga menjadi pelopor yang membawa aneka sambal penyetan dari warung kaki lima ke restoran. Penyetan menjadi spesial karena sambal yang digunakan menggunakan terasi pilihan dan diulek langsung. Konsumen bisa memilih tingkat kepedasan berbeda sesuai dengan selera mereka.

Pelaku usaha ini membuat akun instagram dengan nama Warung $\mathrm{Bu}$ Kris. Banyak kegiatan yang mereka lakukan dalam rangka mempromosikan produk makanannya misalnya dengan mengunggah foto produk, foto konsumen yang sedang menikmati produk menu makanan mereka, memberikan tanggapan kepada pengguna instagram (followers) yang mengomentari foto tersebut.

Iklan produk makanan Warung Bu Kris yang diunggah di media instagram sangat unik, baik itu dari segi penyajian informasi iklan serta 
tampilan produk makanan yang ditawarkan. Warung $\mathrm{Bu}$ Kris cenderung menggunakan slogan-slogan yang berhubungan dengan produk yang ditawarkan, seperi 'Hanya ada 1 jalan menuju menu enak dan penyetan legendaris Warung Bu Kris!!'. Selain itu, iklan produk makanan Warung Bu Kris juga banyak mengandung unsur nonverbal berupa adanya gambar seorang laki-laki yang sedang mengayuh sepeda, logo Warung $\mathrm{Bu}$ Kris, gambar jam dinding, serta gambar menu makanan yang ditawarkan. Unsur-unsur verbal dan nonverbal yang terkandung dalam iklan produk makanan Warung $\mathrm{Bu}$ Kris menjadi objek yang sangat menarik untuk dianalisis lebih lanjut terkait dengan struktur iklan, interpretasi informasi yang terkandung pada iklan, serta pengaruh iklan terhadap keputusan pembelian.

Struktur iklan dapat diklasifikasikan menjadi lima, yaitu headline, illustrations, body copy, signature line, standing details (Leech, 1966). Headline merupakan pembuka sebuah iklan, ilustration sebagai pemberi ilustrasi iklan tersebut, body copy merupakan isi sebuah iklan yang berisi informasi dan pesan iklan, signature line sebagai tampilan produk yang diiklankan, standing details merujuk pada penutup iklan. Selain itu, hal yang terpenting lainnya merujuk pada strategi pemasaran produk melalui iklan. Strategi pemasaran produk melalui iklan meliputi establishing credentials, introducing the offer, offering incentive, enclosing documents, soliciting respons, using pressure tactics, serta ending politely. Beragam informasi pada iklan produk makanan dapat memengaruhi masyarakat dalam hal keputusan pembelian produk makanan tersebut. Pengaruh yang terjadi terdiri dari attitude towards the ad (Kotler. \& Keller, 2009), ad recall (Hening, 2014), dan clik throught rates (Lim \& Lau, 2011). Berdasarkan latar belakang yang telah dikemukakan di atas, maka peneliti memfokuskan pada analisis struktur iklan Warung $\mathrm{Bu}$ Kris. Adapun permasalahan yang diangkat sebagai berikut.

1. Bagaimana struktur iklan produk makanan Warung Bu Kris di media sosial instagram?

2. Bagaimana strategi pemasaran produk makanan Warung Bu Kris di media sosial instagram?
3. Bagaimana pengaruh promosi iklan terhadap keputusan pembelian produk makanan Warung Bu Kris?

\section{METODE}

Metode penelitian merupakan serangkaian tata cara atau langkah yang sistematis dan terstruktur yang dilakukan oleh seorang peneliti dengan tujuan menjawab pertanyaan dari rumusan masalah yang telah ditetapkan. Metode penelitian menjelaskan bagaimana proses penelitian itu dilakukan, mulai dari tahap pengumpulan data hingga penyajian hasil analisis data.

Pengumpulan data dalam penelitian ini dilakukan dengan metode simak dengan teknik dokumentasi. Peneliti mengamati penggunaan unsur verbal berupa kata, frasa, dan kalimat yang terdapat pada iklan produk makanan di akun instagram Warung Bu Kris. Selain itu, peneliti juga mengamati penggunaan berbagai gambar dan ikon sebagai unsur nonverbal iklan tersebut. Kemudian, peneliti melakukan teknik dokumentasi melalui rekam layar iklan tersebut, selanjutnya dikelompokkan.

Data yang telah terkumpul kemudian dianalisis. Metode analisis data yang digunakan dalam penelitian ini adalah metode padan intralingual. Metode padan intralingual merujuk pada metode analisis dengan cara menghubung-bandingkan unsur-unsur yang bersifat lingual, baik yang terdapat dalam satu bahasa maupun dalam beberapa bahasa yang berbeda. Penelitian ini menggunakan teknik analisis data padan intralingual karena teknik ini digunakan untuk menganalisis makna unsur verbal dan nonverbal, sehingga dapat diperoleh interpretasi informasi yang terkandung pada iklan tersebut.

Hasil analisis data kemudian disajikan menggunakan metode formal dan informal. Metode formal dalam penelitian ini merujuk pada tampilan foto produk makanan serta teks penyerta gambar (caption) dari iklan produk makanan Warung Bu Kris, sedangkan metode informal dalam penelitian ini mengarah pada penggunaan kalimat-kalimat sebagai pemberi penjelasan dari tampilan foto produk maupun teks penyerta gambar. 


\section{PEMBAHASAN}

Peneliti telah mengumpulkan iklan produk makanan Warung Bu Kris yang disebarluaskan melalui media instagram. Berikut ini uraian struktur iklan disertai analisis terkait pengaruh iklan tersebut terhadap keputusan pembelian.

1. Iklan dengan struktur headline-illustrationssignature line-body copy-standing details

Gambar 1. Iklan 1

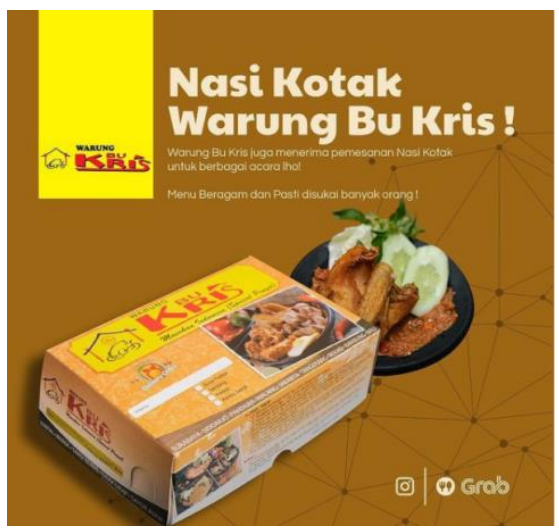

Iklan ini diunggah oleh pemilik usaha Warung Bu Kris melalui instagram tanggal 27 November 2020. Iklan ini dibentuk oleh unsur verbal dan nonverbal. Unsur verbal dapat dilihat dari penggunaan kalimat yang mempromosikan produk makanan di warung tersebut, seperti pada kalimat 'Warung Bu Kris juga menerima pemesanan Nasi Kotak untuk berbagai acara lho'. Kalimat ini mengandung makna bahwa Warung $\mathrm{Bu}$ Kris menawarkan menu makanan yang bisa dipesan untuk keperluan berbagai acara. Untuk mendukung penyampaian informasi ini, maka pemilik Warung $\mathrm{Bu}$ Kris juga menampilkan unsur nonverbal. Unsur nonverbal terlihat dari munculnya tiga gambar, yakni logo Warung Bu Kris, gambar satu porsi menu makanan ayam penyet lengkap dengan lalapan mentimun, kol, daun kemangi, serta gambar sebuah kotak sebagai tempat penyimpanan makanan Warung $\mathrm{Bu}$ Kris, khususnya bagi konsumen yang ingin memesannya untuk acara-acara tertentu. Unsur verbal dan nonverbal ini ditata sedemikian rupa, sehingga membentuk struktur iklan, yang terdiri dari headline, illustration, signature line, body copy, serta standing details. Gambar sebuah kotak makan yang disertai dengan foto tampilan satu porsi ayam penyet khas Bu Kris merupakan headline dari iklan karena keberadaan gambar ini berfungsi sebagai daya tarik (eye catcher) para konsumen terhadap produk makanan di Warung Bu Kris. Kotak makan tersebut terbuat dari kertas karton yang dirancang langsung oleh pihak Warung $\mathrm{Bu}$ Kris. Hal ini dapat dilihat dari logo Warung $\mathrm{Bu}$ Kris yang terdapat pada kotak makan tersebut serta gambar satu menu makanan, yakni ayam penyet. Gambar kotak makan ini mengandung makna bahwa Warung $\mathrm{Bu}$ Kris menerima pesanan makanan untuk acara-acara tertentu, misalnya arisan, ulang tahun, dan lainnya. Pada bagian atas kotak makan tersebut, terdapat gambar logo Warung $\mathrm{Bu}$ Kris sebagai tanda bahwa produk makanan yang ada di dalam kotak tersebut adalah memang benar hasil karya Warung Bu Kris sedangkan, gambar satu porsi ayam penyet pada bagian atas kotak makan tersebut merujuk pada salah satu menu makanan favorit konsumen dan tentunya menu ini dapat dipesan juga dalam kemasan kotak makan.

Di sisi lain, gambar satu porsi ayam penyet lengkap dengan lalapannya juga ada di samping kotak makan. Namun, hal yang membedakan adalah satu porsi ayam penyet tersebut diletakkan di atas cobek dilengkapi sambal dan lalapan timun, kol, serta daun kemangi. Gambar ini mengindikasikan bahwa menu ayam penyet juga bisa dinikmati langsung di Warung $\mathrm{Bu}$ Kris. Iklan ini juga memiliki signature line, yang dapat dilihat dari penggunaan slogan produk makanan yang ditawarkan Warung $\mathrm{Bu}$ Kris. Slogan tersebut tercermin dalam kalimat, 'Menu Beragam dan pasti disukai banyak orang!'. Kalimat ini mengandung makna bahwa Warung $\mathrm{Bu}$ Kris menawarkan banyak varian menu makanan, khususnya menu olahan penyetan dengan rasa yang enak dan lezat sehingga orang-orang pasti menyukainya. Kemudian, bagian iklan di atas yang termasuk body copy adalah pada kalimat 'Warung $\mathrm{Bu}$ Kris juga menerima pemesanan Nasi Kotak untuk berbagai acara lho'. Kalimat ini termasuk body copy karena kalimat ini mengandung informasi yang disampaikan oleh iklan tersebut, yakni Warung $\mathrm{Bu}$ Kris menerima pesanan menu makanan olahan penyetan baik itu ayam penyet, tempe penyet, dan lainnya untuk keperluan berbagai acara, misalnya ulang tahun, arisan, syukuran, seminar, ataupun rapat. Sedangkan bagian iklan yang tergolong 
standing details ditunjukkan melalui ikon instagram dan ikon platform pengiriman makanan siap antar, Grabfood.

Kedua ikon ini ditampilkan dengan tujuan menegaskan kembali bahwa Warung Bu Kris menerima pesanan nasi kotak (menu olahan penyetan yang dikemas dalam kotak makan) untuk keperluan acara tertentu. Pesanan bisa disampaikan melalui pesan langsung (Direct Message) ke akun instagram Warung Bu Kris atau bisa juga dipesan melalui platform GrabFood.

2. Iklan dengan struktur headline-body copystanding details

Gambar 2. Iklan 2

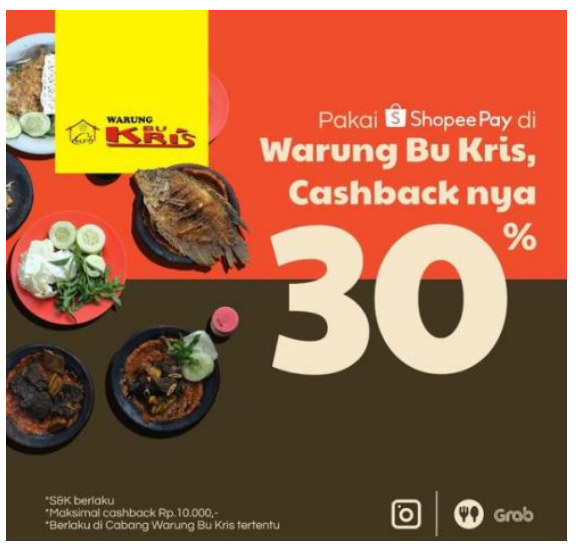

Iklan ini ditampilkan oleh pemilik usaha Warung Bu Kris melalui instagram tanggal 22 September 2020. Iklan ini memiliki unsur verbal dan nonverbal. Unsur verbal dapat dilihat dari penggunaan kalimat-kalimat pada iklan seperti, 'Pakai Shopee Pay di Warung Bu Kris'. Kalimat ini mengandung makna bahwa Warung $\mathrm{Bu}$ Kris menerima pembayaran pesanan makanan via platform Shopee Pay sebagai fitur layanan dompet dan uang elektronik sedangkan unsur nonverbal iklan ini dapat ditunjukkan oleh gambar varian menu makanan yang ditawarkan oleh Warung $\mathrm{Bu}$ Kris, seperti ikan nila penyet, empal penyet, ayam penyet, dan lainnya. Unsur-unsur inilah yang selanjutnya membentuk struktur iklan. Struktur iklan ini terdiri dari headline, body copy, standing details. Bagian yang termasuk headline adalah gambar varian menu makanan di Warung $\mathrm{Bu}$ Kris. Menu-menu ini ditampilkan dengan warna yang menarik dan menyita perhatian. Semua menu penyetan disajikan di atas cobek disertai sambal dan lalapan (mentimun, daun kemangi, serta kol). Kemudian, bagian yang termasuk body copy yakni kalimat 'Pakai Shopee Pay di Warung Bu Kris, Cashbacknya 30\%'. Kalimat ini mengindikasikan bahwa Warung $\mathrm{Bu}$ Kris menerima pembayaran makanan via platform Shopee Pay, yaitu fitur layanan dompet dan uang elektronik. Jika ada konsumen yang ingin membeli makanan di Warung $\mathrm{Bu}$ Kris kemudian membayarnya melalui platform Shopee Pay, maka mereka akan mendapatkan uang Kembali (cashback) sebesar 30\%. Mereka akan mendapatkan pengembalian uang tunai atas makanan yang sudah dibeli, dan pengembalian uang tunai tersebut sebesar $30 \%$ dari harga makanan tersebut sedangkan bagian iklan yang termasuk standing details adalah beberapa frasa seperti ' $\mathrm{S} \& \mathrm{~K}$ berlaku', 'Maksimal cashback Rp. 10.000', 'Berlaku di Cabang Warung $\mathrm{Bu}$ Kris tertentu', ikon instagram, serta ikon Grabfood. Beberapa frasa yang ada pada iklan memberikan informasi tambahan bahwa adanya syarat dan ketentuan terkait cashback yang diberikan. Syarat dan ketentuan tersebut memperjelas cashback yang diberikan, yakni maksimal cashback Rp. 10.000. Cashback ini hanya berlaku di beberapa cabang Warung $\mathrm{Bu}$ Kris sedangkan ikon instagram dan Grabfood juga berfungsi sebagai pemberi informasi tambahan berkenaan dengan pemesanan makanan di Warung Bu Kris dapat dilakukan via direct message (DM), fitur pengiriman pesan pada media instagram, atau bisa memesan makanan via platform Grabfood.

\section{Iklan dengan strategi establishing credentials dan pressure tactics}

Gambar 3. Iklan 3

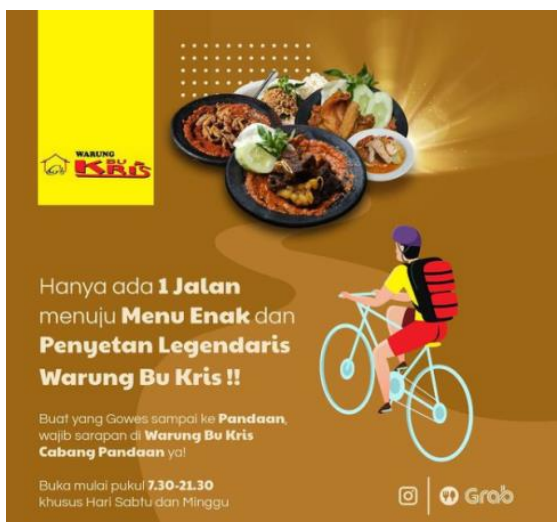


Iklan ini diunggah ke media instagram pada tanggal 21 November 2020. Iklan ini mengandung unsur verbal dan nonverbal. Unsur verbal pada iklan ditunjukkan oleh penggunaan tiga kalimat. Kalimat (1) yaitu 'Hanya ada 1 jalan menuju Menu Enak dan Penyetan Legendaris Warung $\mathrm{Bu}$ Kris!'. Kalimat pertama mengindikasikan bahwa Warung yang satu-satunya menyediakan menu penyetan dengan rasa yang enak dan tentunya telah dikenal di kalangan masyarakat adalah Warung $\mathrm{Bu}$ Kris. Warung $\mathrm{Bu}$ Kris menggunakan strategi iklan establishing credentials. Warung Bu Kris mempromosikan produk makanan yang dijual melalui pemberian bukti kelayakan. Bukti kelayakan tersebut ditunjukkan oleh kalimat 'Penyetan Legendaris Warung Bu Kris'. Warung Bu Kris sudah dikenal masyarakat sejak tahun 1996 sebagai warung yang menawarkan varian menu penyetan yang disajikan di atas cobek dan disertai sambal yang rasanya khas. Sambal tersebut dibuat menggunakan terasi pilihan (Godjali, 2019). Diolah secara tradisional, terasi tersebut didatangkan dari Surabaya ke semua cabang Warung Bu Kris. Keunikan lainnya adalah sambal diulek secara langsung dan konsumen bisa memilih tingkat kepedasan sesuai selera mereka. Kalimat (2) yaitu 'Buat yang Gowes sampai ke Pandaan, wajib sarapan di Warung Bu Kris, cabang pandaan ya!'. Kalimat ini mencerminkan bahwa pemilik usaha Warung $\mathrm{Bu}$ Kris menggunakan strategi pemasaran pressure tactics. Frasa 'Buat yang Gowes sampai ke Pandaan' bukan merujuk hanya pada konsumen yang suka gowes (kegiatan bersepeda bersama teman-teman) saja melainkan ditujukkan untuk semua konsumen. Pemilik usaha Warung $\mathrm{Bu}$ Kris menuliskan frasa di atas pada iklannya seiring dengan tren atau kecenderungan masyarakat saat ini yang sangat suka bersepeda bersama teman-temannya di pagi hari sejak pemerintah menerapkan era new normal (tatanan kehidupan baru sebagai upaya mempercepat penanganan pandemi COVID-19 di Indonesia dalam aspek kesehatan maupun sosialekonomi) (Suparjo, 2020). Bahkan hasil surevei dari The Institute for Transportation and Development Policy (ITDP), pengguna sepeda meningkat hingga 10 kali lipat atau setara $1.000 \%$. Seiring tren gowes (bersepeda) ini meningkat secara signifikan, maka pemilik usaha Warung $\mathrm{Bu}$ Kris menganggap bahwa mayoritas masyarakat yang akan menjadi konsumennya akan berasal dari pengguna sepeda. Pada umumnya, masyarakat yang suka bersepeda (gowes) tidak menempuh jarak yang dekat, namun sebaliknya mereka cenderung bersepeda dengan jarak yang cukup jauh, bisa lebih dari 1.000 kilometer. Sehingga, pada iklan $\mathrm{di}$ atas, pemilik Warung $\mathrm{Bu}$ Kris mencantumkan frasa keterangan tempat 'sampai ke Pandaan'. Pandaan merupakan sebuah kecamatan yang ada di Kabupaten Pasuruan, Provinsi Jawa Timur, Indonesia. Letaknya sangat strategis, berada di tengahtengah jalur Malang-Surabaya dengan akses menuju tempat wisata yang menarik. Warung Bu Kris sudah dibuka saat pagi hari pukul 07.30 (khusus Sabtu dan Minggu), maka mereka mengganggap masyarakat yang sedang bersepeda (gowes) di tengah-tengah jalur Malang-Surabaya yang akan mengunjungi warungnya untuk menikmati beragam menu penyetan yang enak dan lezat. Kemudian, kalimat (3) yaitu 'Buka mulai pukul 07.3021.30 khusus hari Sabtu dan Minggu'. Kalimat ini memberikan informasi mengenai jadwal dibukanya Warung Bu Kris, khusus pada hari Sabtu dan Minggu yaitu jam 07.30-21.30. Jadwal dibukanya Warung Bu Kris lebih pagi khusus hari Sabtu dan Minggu, karena kecendrungan masyarakat yang berekreasi melalui aktivitas gowes lebih sering pada hari tersebut. Selain unsur verbal, iklan ini juga mengandung unsur nonverbal. Unsur nonverbal tersebut dapat dilihat dari logo Warung Bu Kris, gambar menu makanan, seseorang yang sedang mengayuh sepedanya, ikon instagram, serta ikon Grabfood. Logo Warung $\mathrm{Bu}$ Kris ditampilkan pada iklan sebagai suatu pengakuan dari sebuah merek usaha yang dijalankan. Pada logo tersebut, terdapat gambar rumah. Gambar rumah dengan desain yang sederhana menunjukkan bahwa Warung $\mathrm{Bu}$ Kris didasari dari usaha menjual menu penyetan di rumah pribadi. Pemilik usaha Warung $\mathrm{Bu}$ Kris ini adalah $\mathrm{Bu}$ Kris dengan anak perempuannya yang bernama Roesmiharti tahun 1996 di Surabaya (Godjali, 2019). Sedangkan varian menu makanan menggambarkan secara jelas kepada masyarakat khususnya dari segi penyajian 
makanan tersebut. Penyajian makanan di Warung $\mathrm{Bu}$ Kris yang khas berbeda dari warung lainnya, karena semua menu penyetan disajikan di atas cobek disertai dengan sambal dengan rasa pedas sesuai level yang dipilih konsumen. Adanya seseorang yang sedang mengayuh sepedanya merujuk pada konsumen yang dominan akan datang dan mengunjungi Warung Bu Kris saat 07.30 pagi di hari Sabtu dan Minggu. Namun, bukan berarti pengunjung yang menggunakan mobil ataupun sepeda motor tidak boleh menikmati menu makanan Warung Bu Kris. Sedangkan ikon instagram dan Grabfood mengarahkan masyarakat untuk bisa menggunakannya sebagai fitur pemesanan online. Masyarakat bisa memesan makanan yang ingin dibeli via direct message (DM), yaitu mengirim pesan ke akun instagram Warung Bu Kris untuk memesan makanannya. Selain itu, bisa juga dengan memanfaatkan Grabfood, yaitu platform pengiriman makanan online yang bisa mengantarkan makanan sesuai dengan lokasi konsumen.

\section{Iklan dengan strategi offering incentive dan pressure tactics}

Gambar 4. Iklan 4

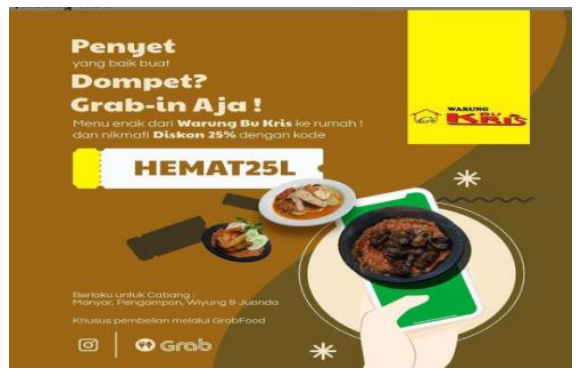

Iklan ini diunggah oleh pemilik usaha Warung Bu Kris pada tanggal 20 Oktober 2020. Pada iklan ini, terdapat unsur verbal dan unsur nonverbal yang mencerminkan strategi pemasaran yang digunakan. Unsur verbal dapat dilihat dari penggunaan satu kalimat dan satu kata pada iklan. Satu kalimat tersebut merujuk pada kalimat 'Menu enak dari Warung Bu Kris ke rumah! dan nikmati diskon 25\%'. Kalimat ini mengindikasikan strategi pemasaran offering incentive, dimana pemilik usaha Warung Bu Kris memberikan diskon, yakni pengurangan harga makanan dari harga biasa, jika konsumen memesan sekaligus membayar makanan yang mereka beli melalui platform
Grabfood. Unsur verbal juga terdapat pada kata 'HEMAT25L'. Kata ini mencerminkan kode yang harus digunakan konsumen saat memesan sekaligus membayar via Grabfood. Kata 'HEMAT25L' ditulis dengan huruf kapital. Kata ini mencerminkan bahwa Warung Bu Kris menggunakan strategi pressure tactics, dimana mereka menekankan diskon (potongan harga) sebesar $25 \%$ jika memesan sekaligus membayar makanan via Grabfood. Selain unsur verbal, terdapat pula unsur nonverbal pada iklan ini. Unsur nonverbal merujuk pada gambar tiga varian menu penyetan (empal penyet, ayam penyet, serta tahu penyet), gambar handphone, gambar piring, logo Warung Bu Kris, ikon instagram, serta ikon GrabFood. Tiga gambar menu penyetan mengindikasikan bahwa konsumen bisa membeli salah satu dari tiga menu tersebut. Mereka bisa membeli empal penyet, ayam penyet, atau tahu penyet. Semua tergantung dari selera makan mereka. Kemudian, gambar handphone melambangkan sarana untuk akses platform Grabfood, fitur pembelian, pembayaran, serta pengiriman makanan berbasis online. Gambar piring menunjukkan bahwa setelah makanan dipesan, dibayar via Grabfood, maka kurir Grabfood akan mengantarkan makanan tersebut sampai rumah konsumen. Ketika makanan telah tiba di rumah konsumen, maka makanan penyetan yang telah dipilih dapat dinikmati. Logo Warung Bu Kris mencerminkan kualitas produk makanana yang ditawarkan. Ikon instagram dan Grabfood mengindikasikan bahwa konsumen bisa memesan secara online.

\section{Iklan pada attitude towards the ad}

Gambar 5. Iklan 5

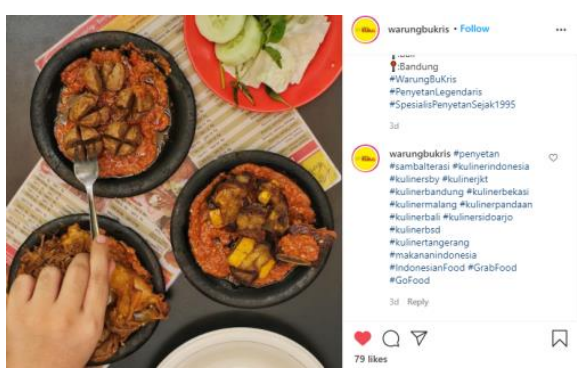

Iklan ini diunggah di akun instagram Warung Bu Kris tanggal 27 November 2020. 
Iklan ini mengandung unsur verbal dan nonverbal. Unsur verbal dapat dilihat melalui kalimat-kalimat yang menginformasikan bahwa makanan di Warung $\mathrm{Bu}$ Kris dapat dicoba langsung di beberapa cabang Warung $\mathrm{Bu}$ Kris maupun dilakukan melalui aplikasi GoFood dan GrabFood sedangkan, unsur nonverbal ditunjukkan dari munculnya tiga gambar, yakni gambar tangan, garpu, serta beberapa makanan. Gambar makanan yang terdiri dari tiga olahan penyetan, yaitu ayam penyet, bakso penyet, dan empal penyet yang disertai sambal di dalam cobek. Gambar ini merepresentasikan menu makanan andalan Warung $\mathrm{Bu}$ Kris, yaitu menu penyetan, dimana ayam, bakso, maupun empal ditekan diatas cobek yang berisi sambal agar bentuknya pipih namun teksturnya tidak sampai hancur. Selain itu, pada iklan diatas juga terdapat gambar tangan dan gambar sebuah garpu. Kedua gambar ini menunjukkan seorang konsumen yang sedang mencicipi makanan tersebut.

Pemasaran iklan diatas dapat mempengaruhi keputusan pembelian dalam hal attitude towards the ad. Ketika iklan tersebut diunggah di akun instagram Warung Bu Kris, maka munculah respon dari masyarakat pengguna instagram. Hal ini dapat dilihat dari icon like, yaitu tanda hati berwarna merah yang berada di pojok kiri iklan tersebut. Jumlah yang tercantum adalah 79. Jumlah ini mengindikasikan bahwa masyarakat menyukai menu-menu makanan di Warung $\mathrm{Bu}$ Kris. Masyarakat memberikan evaluasi yang positif terhadap iklan tersebut. Melalui respon positif ini dapat menjadi dasar keputusan sejumlah masyarakat untuk membeli beberapa menu penyetan Warung Bu Kris.

\section{Iklan pada click throught rates}

Gambar 6. Iklan 6

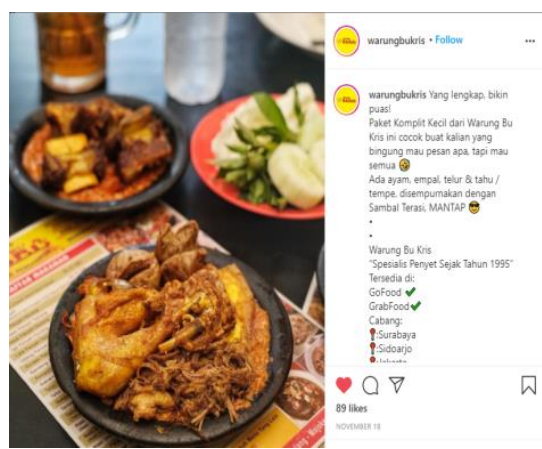

Iklan ini diunggah oleh pemilik akun instagram Warung $\mathrm{Bu}$ Kris tanggal 18 November 2020. Iklan ini mengandung unsur verbal dan nonverbal. Unsur verbal ditunjukkan melalui kalimat-kalimat yang menginformasikan bagi masyarakat yang ingin menikmati semua menu penyetan, Warung $\mathrm{Bu}$ Kris menyediakan paket komplit kecil yang terdiri dari penyetan ayam, tahu, telur, tempe, serta empal. Sementara itu, bagian iklan yang tergolong unsur nonverbal adalah beberapa gambar makanan dan minuman. Gambar makanan yang terdiri dari paket komplit penyetan, daftar menu makanan, penyerta lalapan berupa timun, daun kemangi, serta kol mengindikasikan makanan yang dijual di Warung $\mathrm{Bu}$ Kris dan tentunya dapat dicoba langsung di warung atau dipesan melalui aplikasi GoFood dan GrabFood. Kemudian, gambar daftar menu mengandung makna bahwa paket komplit penyetan termasuk menu terbaru sebagai bentuk inovasi Warung Bu Kris sesuai minat masyarakat yang saat ini ingin menikmati makanan secara praktis sedangkan, gambar minuman berupa es teh dan air mineral yang dingin ini melengkapi rasa nikmat makanan penyetan dari Warung Bu Kris.

Pemasaran iklan diatas dapat mempengaruhi keputusan pembelian dalam hal click throught rates. Saat iklan tersebut diunggah di akun instagram Warung Bu Kris, maka muncullah respon atau tanggapan dari sejumlah masyarakat pengguna instagram. Hal ini dapat dilihat dari ikon like serta fitur komentar pada postingan iklan tersebut. Ikon like yang dilambangkan dengan tanda hati berwarna merah menunjukkan angka 89 disertai 3 komentar dari masyarakat pengguna instagram. Ini mengindikasikan bahwa sejumlah masyarakat pengguna instagram telah memberikan ulasan (review) atau tanggapan melalui fitur-fitur di instagram. Review yang diberikan dalam bentuk review positif. Dengan kata lain, iklan tersebut mampu menarik minat dan perhatian sejumlah masyarakat pengguna instagram agar menikmati varian menu penyetan olahan Warung Bu Kris.

\section{SIMPULAN}

Iklan produk makanan Warung $\mathrm{Bu}$ Kris yang diunggah di akun instagram mengandung unsur verbal serta nonverbal. Unsur-unsur ini 
yang selanjutnya ditata sedemikian rupa sehingga membentuk struktur iklan meliputi headline-illustrations-signature line-body copy-standing details serta headline-body copy-standing line. Struktur iklan mencerminkan strategi pemasaran yang digunakan oleh pemilik Warung Bu Kris, yang terdiri dari establishing credentials, pressure tactics, serta offering incentives. Iklan yang ditampilkan melalui instagram tersebut dapat memengaruhi keputusan pembelian produk makanan Warung Bu Kris, terutama dalam hal attitude towards the ad serta click throught rates.

\section{DAFTAR PUSTAKA}

Anam, H. M. (2015). Pesan Hidup Sehat dalam Iklan Televisi. Universitas Islam Negeri Sunan Kalijaga.

Godjali, H. D. (2019). Buah Mendengarkan Pelanggan.

https://avonturkuliner.wordpress.com/20 19/12/04/buah-mendengarkan-

pelanggan/
Hening, A. P. (2014). Pengaruh Iklan Online Melalui Facebook Terhadap Keputusan Pembelian Pakaian Mahasiswa Fakultas Ekonomi dan Bisnis Universitas Trunajaya Madura. Jurnal Studi Manajemen, 8(1).

Kotler., \& Keller, K. (2009). Manajemen Pemasaran. Erlangga.

Leech, G. N. (1966). English in Advertising: Linguistic Study of Advertising in Great Britain. Longman.

Lim, Y. M., \& Lau, C. T. (2011). The Effectiveness of Online Advertising in Purchase Decision: Liking, Recall and Click. Australian Journal of Basic and Applied Sciences, 5(9).

Suparjo. (2020). Tren Gowes Meningkat saat Covid-19, Saatnya Bangun Infrastruktur Khusus Sepeda. https://economy.okezone.com/read/2020 /07/14/320/2246208/tren-gowesmeningkat-saat-covid-19-saatnyabangun-infrastruktur-khusus-sepeda 